\title{
CHALLENGES IN TRANSLATION OF ENGLISH PHRASEOLOGICAL UNITS WITH ONOMASTIC CONSTITUENTS INTO VIETNAMESE EQUIVALENTS
}

\author{
Nguyen Viet Khoa* \\ School of Foreign Languages, Ha Noi University of Science and Technology, \\ No. 1 Dai Co Viet Road, Ha Noi, Viet Nam \\ Received 4 February 2021 \\ Revised 11 March 2021; Accepted 15 May 2021
}

\begin{abstract}
Translation of phraseological units with proper names (PUPs) is topical for the contemporary translation studies nowadays. It is noted that PUPs reflect the culture and national mentality of a definite nation. Quite a few studies have prospectively examined English PUPs and their translation into other languages, but it is hard to find such an in-depth study in the case the target language is Vietnamese. By employing the qualitative approach, this paper sets out the findings of the study where 241 English PUPs in our compiled database were classified into four groups according to their translations into Vietnamese. The group of non-idiomatic and descriptive translation equivalents accounts for a majority of more than 57\% of all the PUPs, proving that PUPs in both languages are highly culture-specific. Although the other three groups share a minority of approximately $43 \%$ of all the PUPs, they hold interesting implications and multiple levels of similar or different metaphors. Based on the findings, the paper discusses the challenges translators encounter during the translation process of English PUPs into their Vietnamese equivalents. It is evident that among various translation obstacles, the proper name factor is clearly one of the most challenging issues. The paper then proposes some translation solutions to cope with these special expressions. In addition to recommending to flexibly apply translation strategies, the author's conclusion emphasizes that only when translators manage to decode and grasp how PUPs work cross-linguistically in both languages and cultures can they achieve an appropriate translation of English PUPs.
\end{abstract}

Key words: phraseological unit, proper name, onomastics, idiom, fixed expression

\section{Introduction}

A phraseological unit is a word group with a fixed lexical composition and grammatical structure; its meaning, generally figurative and cannot be derived from the meanings of the phraseological unit's constituents (Kunin, 1970; Gläser, 1988). As an important part of each language, phraseological units (PUs henceforth) contain the sociolinguistic and

\footnotetext{
* Corresponding author.

Email address: khoa.nguyenviet@hust.edu.vn

https://doi.org/10.25073/2525-2445/vnufs.4624
}

sociocultural characteristics of a community, a people and even a nation. A proper name is a phrase that names a specific object or entity. As the study object of onomastics, proper names also attract a lot of interest of researchers from other sciences such as philosophy, logics, and history, but only onomasticians, with a different focus and approaches, could bring about fresh and effective research results (Belecky, 1972; Algeo, 1973; Nuessel, 1992; Hough, 2000; 
Coates, 2006; Van Langendonck, 2007; Anderson, 2007).

It is observed that researchers seem to be giving more focus on the theoretical issues of proper names and onomastics, while their specific problems in each language when compared to those in another language have not been put under much care. For example, how will English PUs with proper names such as a Jack of all trades, the real McCoy or send someone to Coventry be translated into Vietnamese so that they are considered "well-translated" or their message is well communicated to the Vietnamese audience when each PU of this type possesses a unique characteristic of British culture?

Translation is a challenging process that is not just about transferring words and terms. Rather, it is a matter of the relationship between language and culture. The larger the gap between the source language culture and the target language culture, the harder it is to translate, and the difference between English and Vietnamese culture is not an exception. Proper names and their derivatives which are constituent elements of PUs are determined as onomastic constituents. PUs with onomastic constituents or proper names (PUPS henceforth) are considered part of culture, requiring language translators to have a cultural background proportionally similar to that of native speakers to bridge the cultural gap in the process of translation. Therefore, it is elicited that translation of PUPs or PUs with proper names should also be approached from the cultural standpoint.

By "translators" we mean persons who translate from one language into another, especially as a profession, thus ones with good command of the language. To avoid unnecessary confusion, the term "translators" or "the translator" is agreed to use throughout the paper to refer to both student or trainee translators and translation professionals.
For translators, having a firm grasp of the lexical and cultural meaning of a PUP is a prerequisite before finding its equivalent in the target. During this process, cultural differences between the two languages must be taken into account. Researchers in linguistics and translatology such as Nida (1964), Bassnett-McGuire (1980), Newmark (1988), Baker (1992), Davies (2004), Langlotz (2006) etc., highlight the great importance of linguistic and cultural knowledge in grasping PUPs. Language is approached in relation to culture in order to define how culture and language overlap. Only in comparison to another language can a PUP be considered as culture-specific and can ethnolinguistic problems be defined; thus, when contrasting two languages, this feature comes to the fore. As Dobrovol'skij, Piirainen and Dobrovolskij (2005, p. 245) stress, speakers perceive PUs with a proper name typical of a given national culture as "being culturally connoted". Also, we share the viewpoints on difficulties and strategies in the translation of idioms and fixed expressions proposed by Baker (1992), Leppihalme (1997), Newmark (1988) and Davies (2004).

With that approach, the paper first aims to explore English PUs with onomastic constituents (or with proper names in a more specific term, PUPs), regardless of anthroponyms, toponyms and ethnonyms, or their derivatives and propose directions for translating them into Vietnamese. We will then analyze challenges that translators would encounter when translating English PUPs into Vietnamese, put them into groups according to their Vietnamese equivalents, and propose solutions to cope with them in the translation process.

\section{Theoretical Background}

\subsection{Proper Names}

In terms of proper name, it is a must to distinguish it from the proper noun. 
A proper noun is a noun identifying a single entity and is used to refer to that entity as opposed to a common noun, which refers to "a class of entities" (Anderson, 2007, pp. 3-5). In other words, proper nouns are nouns denoting unique entities such as Ha Noi, London, Jack, Jane, Tuan, or Thu Hang. In principle, in English, Vietnamese and many other languages, proper nouns are capitalized. Grammatically, as Huddleston (1988, p. 96) observes, a proper noun is noun subclass, whilst a proper name is "the institutionalized name of some specific person, place, organization, etc., institutionalized by some formal act of naming and/or registration". As a characteristic of a given culture, proper names should be observed from different points of view, ranging from historical and geographical to cultural, linguistic, crosslinguistic and social.

Van Langendonck (2007, p. 116) proposes that a proper name should be considered a noun or noun phrase that denotes a unique entity "at the level of established linguistic convention". Coates (2006) accentuates that the properhood of a name, whether given to a person or place, distinguishes an individual or a named object from all unnamed individuals or things. Lyons (1977) points out that proper names constitute a system organized in accordance with criteria varying across cultures and act as a reflection of the society of which they are the expression. They are linguistic items fulfilling a referential function, i.e., they refer to single entities existing in the real world.

As regards their translation from the source language into the target language, proper names are often peculiar because they are mostly not translated between languages, although they can be transliterated, morphologically adapted to the target

\footnotetext{
${ }^{1}$ Other terms include phraseme, multi-word lexical unit, fixed expression, fixed phrase, phrasal lexeme,
}

language, culturally adapted or substituted (Hermans, 1988). Therefore, as Weiss (2019) comments, proper names are so closely connected to a language that they cannot be effectively translated; instead, it is necessary to recreate the conditions of the possibility of acts of onomastic denomination.

All languages have particular proper names, some of which are deeply rooted in the culture of the speakers of the specific language; consequently, they can pose unique difficulties in the comprehension of culturespecific texts. It is interesting to note that some proper names have specific connotations, and omitting this implicit information results in unacceptable translation. For instance, in the Vietnamese culture, Manh Thuong Quan the name of a very generous man in Chinese stories - is a symbol of generosity; accordingly, if a translator, unaware of this fact, encounters this sentence "Sếp của tôi là Mạnh Thuờng Quân" (»My boss is Manh Thuong Quan) in a conversation of two friends talking about the traits of their boss, the translator may erroneously assume that the speaker is presenting the name of his employer, not his personality.

When a certain name has entered the common memory of the nation and becomes the common property of the linguistic community, its cultural connotation and specificity will gradually fade away. To perceive and translate idiomatic combinations with such names is indeed a huge challenge.

\subsection{Phraseological Units}

A regular question may be asked: What is a PU? Different terms are used by various scholars in the field of phraseology to refer to a series of two or more words operating as a whole, and a single term may be used in reference to different phenomena. ${ }^{1}$ The lack of standardized

phrasicon, phraseological unit (Lyons, 1977; Cowie, 1998; Moon, 1998; Fiedler, 2007). 
terminology is attributed by Granger and Meunier (2009, p. xix) to the fact that phraseology has only recently been known as a "discipline in its own right". They specify that it deals with the study of word combinations rather than single words and that, based on the following parameters, these multi-word units are categorized into different subtypes: degree of semantic noncompositionality, syntactic fixedness, lexical restrictions and institutionalization.

'Idiom' is definitely a commonly used term that most monolingual English dictionaries use to incorporate a section listing multi-word lexical objects, whether or not semantically opaque, in addition to the term 'phrases'. Idioms are fixed groups of words having stable forms and fully figurative meanings, e.g., as drunk as a fish; to get one's blood up or nhát nhu cáy; su tü Hà Đông (Long \& Summers 1996; Hoang, 2008, as cited in Dang, 2011). According to Moon (1998, pp. 3-5), 'idiom' is an ambiguous term that is used "only occasionally to apply loosely to metaphorical expressions" that are semitransparent and opaque, e.g., kick the bucket or spill the beans. The term 'fixed expressions and idioms', which covers different kinds of phrasal lexemes, phraseological units, or multi-word lexical items, including idioms is Moon's preference.

As Kunin (1970, p. 210) outlines, 'Phraseological unit' is a term that is increasingly used to denote "a stable combination of words with a fully or partially figurative meaning". Gläser (1998, p. 125 , as cited in Vrbinc, 2019, p. 11) describes a 'Phraseological unit' as a "lexicalized, reproducible bilexemic or polylexemic word group" in common use, which has relative syntactic and semantic stability, may be idiomatized, may carry connotations, and may have an emphatic or intensifying function in a text, e.g., to kick the bucket; go Dutch, Greek gift or me tròn con vuông; ba đâu ngồi đấy. Pierini (2008) defines that a phraseological unit or expression is a "sequence constituted by at least two independent lexical items, stored as a unit in lexis" whose basic features are: a) fixedness (multiword unit, fixed in syntax as well as lexis - Adam's apple not David's apple); b) institutionalisation (conventionalized unit - White House; đặt cuc gach); and c) non-compositionality (global meaning not predictable from the meaning of constituent words - the man on the Clapham omnibus; cửa Khổng, sân Trình).

In this paper, we agree with Vbric (2019) that the term phraseological unit is used to name a two or multi-word lexical item with fixed syntax and lexis, which is conventionalized and semantically stable. In other words, the PU is used to refer to idiomatic and fixed expressions, representing the pragmatic aspect of words and word strings in context, and their meaning is not a regular sum of the meanings of each component in the lexical combination.

\section{Translation of English Phraseological Units With Onomastic Constituents}

PUs cross-linguistically share views of life, philosophies, rules, cultural norms and ethics, amongst others. Therefore, it should be mentioned that PUs with proper names reflect the culture and national mentality of a definite country and nationality. English PUPs fall into the following categories: 1) idioms; 2) irreversible binomial; 3) stereotyped simile; 4) formula (see also Gläser, 1998; Moon, 1998; Pierini, 2008).

The first type is a word group having the structure of: a noun phrase (the Midas touch); a verb phrase (rob Peter to pay Paul); a prepositional phrase (according to Hoyle), or an adverb phrase (before you can say Jack Robinson). The second type is a 
pair of two words belonging to the same part of speech joined by 'and' and occurring in a fixed order (Jekyll and Hyde; David and Goliath). The third type is about similes using words like and as (happy as Larry; fight like Kilkenny cats). The fourth type is the 'formula', a situation-based expression serving a specific discursive function, typically occurring in spoken discourse (it's Murphy's law; and Bob's your uncle).

The relationship between translation and culture is highlighted by Saleh and Weda (2018). According to these researchers, culture has inextricably been linked to translation since its inception. Intercultural competence and awareness are required in translating across cultures with focus on the interaction between translation and culture and the way culture impacts translation.

The types of the translation of PUs offered by Kunin (1970) may be well applied for translating interculturally decoded subjects such as PUPs. The only and foremost challenge is the proper name factor. Translating a PU into a natural target language PU, which has the same meaning and impact as the original source language one, is the ideal translation strategy for PUs. However, this always matters. As learnt from the translation strategies suggested by Newmark (1988) and Larson (1984), idioms should never be literally translated. However, in many cases "literal translation of L2 idioms may also be useful as a pathway to comprehension and memorization" as long as the distinction between word-for-word and global meanings of idioms and standard collocations has to be made clear (Newmark, 1991, p. 61).

Nida and Taber (1982, p. 106) refer to the translation of idioms "in terms of semantic adjustments" which may be of three different kinds: from idioms to idioms, from idioms to non-idioms and from non- idioms to idioms. A similar stance is taken by Newmark (1988) who lists three main strategies of translating idioms: finding another metaphor, reducing to sense and literal, word-for-word translation. Baker (1992, pp. 68-78) suggests five main strategies of translating idioms and fixed expressions as follows: and form

1) Using an idiom of similar meaning

2) Using an idiom of similar meaning but dissimilar form

3) Translation by paraphrase

4) Translation by omission

5) Translation by compensation

Translating PUPs is one of the most challenging tasks for a translator. It should be noted that PUPs may have their roots in language history (Gläser, 1988) and can have deep roots, date back many centuries, and be traceable across many languages. Research on PUPs in different languages raises two issues: the universality of some human situations and the cultural specificity. If PUPs include components bearing connotations of local character, they may be more difficult to decode, or they may only be properly decoded provided that adequate context is provided (Szerszunowicz, 2008). Awwad (1990, pp. 57-67) considers two areas of difficulty when translating idioms that can be those of PUs: a) misinterpreting the intention of the writer or speaker and b) recognizing the cultural differences among languages.

The problem is not only to replace the vocabulary and grammar, but also to replace the basic linguistic elements of the source language. It is learnt from BassnettMcGuire (1980) that PUPs should be translated on the basis of the function of the expression: the source language PU should be replaced by a target language PU that has the same meaning. Baker (1992, pp. 68-78) contends that idioms and fixed expressions 
are culture-specific and thus not necessarily untranslatable. Difficulties to translate these units do not come from themselves but the meaning they convey and their associations with culture-specific contexts. Davies (2004) also enlists some difficulties regarding the translation of idioms and fixed expressions, which show close similarity to the ones described by Baker (1992): recognition; no equivalent in the target language; a similar counterpart in the target language with a different context of use; an idiom used in the source text both in its literal and idiomatic sense at the same time; difference between the convention, context, and frequency of use in the source and target languages.

It is believed that in the translators' struggle to attain naturalness all of the above problems and difficulties may arise. As observed by Newmark, the level of naturalness achieved in a translation may depend on whether it makes sense, reads naturally, and "is written in ordinary language, the common grammar, idioms and words that meet that kind of situation" (1988, p. 24).

It can be seen that a large number of English PUPs carry within them the identity of British culture due to the role of English as the "glue" that binds groups of Englishspeaking people together. When converted to Vietnamese, some English PUPs have direct similarities in meaning and basic ideas, but the details may differ. However, there are also PUPs only available in English, and thus the translation must describe, reflect, or explain their nature and meaning, although the metaphor, metonymy or parable is not similar. Consequently, despite being translated, a full equivalence is still out of reach. Therefore, it is important to consider how PUPs operate interlinguistically in other languages and cultures.

Many PUPs are motivated by extralinguistic phenomena belonging to the "collective memory of a given nation" (Szerszunowicz, 2008, pp. 118-119). In this case, as indicated by Pierini (2008, p. 7), denotational and connotational meaning is established by "extracting important pieces of information from world knowledge associated with each of them". If this is not the case, the decoding process of such a PU may pose problems or even lead to incorrect interpretation or translation (see also Szerszunowicz, 2008; Dobrovol'skij, Piirainen \& Dobrovolskij, 2005).

Last but not least, it is necessary to mention omission, compensation, false friend and partial equivalence in translation of PUPs.

In terms of omission, as Baker (1992) insists, it is established that omission is applied when a PUP has no close match Vietnamese, its meaning cannot be easily paraphrased, or for stylistic reasons. It is clear that if the omission is to avoid the lengthy explanation and the inexistence of the PUP does not affect the whole meaning of the text, then the use of omission can be regarded as justifiable. It is necessary to note that when a PUP is omitted, nearly always there is a "loss" in the meaning. To "compensate" the resulting loss, one is obliged to mention some supplementary words in some parts of the sentence or paragraph where an omission has been done (Shojaei, 2012). Let us study this example of a PUP translated by omission: If I ever have to do a Lord Lucan and flee the country, this is where I'll head. » Nếu phải biến mất khỏi đất nước mình, đây là nơi tôi sẽ tới (see also Section 6.3.4).

On compensation, it may be implied that at the point where a PU appears in the source text, one may either omit or play down a function such as idiomaticity and add it elsewhere in the target discourse. It is learnt from Nida and Taber (1982), Larson (1984); Baker (1992) that compensation is 
most definitely worth considering to make up for the loss caused by translating. Therefore, in order to preserve the idiomaticity of the original text and to avoid the mentioned loss, it is recommended that the translator resorts to compensation in translating PUPs as their final but workable strategy. That is when a PUP is not possible to be translated into Vietnamese, the translator's last effort is to compensate the PUP by omitting the PUP and putting it in another place, thus maintaining the stylistic effect of phraseological usage in English. However, compensation should be "the last resort to be used" to ensure that translation is possible (Newmark, 1991, pp. 143-144).

False friend and partial equivalence pose other issues. 'False friend', a term used by Koessler and Derocquigny (1928), as cited in Aronoff and Rees-Miller (2003, p. 698), refers to the state when a word suddenly gets different meanings in two languages, although they have the same origin and appear alike. It results from the fact that language is a living organism and under constant change. Over the years, a word can change its meaning for different reasons. However, a 'false friend' can also arise even if the words do not have the same origin or are loaned from the same language. In partial equivalence (or semi-equivalence), the contents or domains of the concepts differ from each other due to the absence of one or more equivalence aspects (Catford, 1988). The PUP a good Samaritan and its Vietnamese equivalent Mạnh Thuờng Quân is a good reference to the idea of false friend and partial equivalence in translation.

In terms of information and efficiency, it is our intention to consider the following three translation methods: verbatim translation (literal translation lexical meaning), verbatim translation with annotation, explanation, and use of equivalent PUs in the target language. We will analyse the challenges and difficulties translators might encounter when translating
PUPs from English to Vietnamese in the next section of the paper.

\section{Methodology}

As aforementioned in Section 2.1, the views of name scholars differ as regards a straightforward, clear and satisfactory definition of proper names. To avoid unnecessary confusion, we included only those proper names that can be considered the purest and least controversial representatives of the class and that are typically classified as proper names in English. That is to say the compiled database includes PUs with anthroponyms and toponyms and excludes all extreme cases.

Based on our private collection of English idioms containing 8561 entries saved in CSV file format, we used stringsearching algorithms (RegEx) provided by the two powerful, all-purpose text and code editors, Notepad ${ }^{++}$and BBEdit, to process and parse the data in the CSV file in order to filter out the idioms and fixed expressions with proper names. By this way, an initial list of PUs with proper names was made and saved in the MS Excel format. The list is supplemented by adding PUs with onomastic elements from the following three English monolingual idiom dictionaries: (1) All English Idioms \& Phrases. MS Apps. Google Play Store; (2) Oxford Dictionary of English Idioms (2009). Oxford University Press; (3) The Farlex Dictionary of Idioms at https://idioms.thefreedictionary.com. The meaning and usage of each PUP were then double-checked using the electronic and online platforms provided by (1) and (3). As a result, we were able to compile a database of 241 English PUs with onomastic constituents.

The collected PUPs were searched for in the following corpora: British National Corpus and Corpus of Contemporary American English (https://www.englishcorpora.org) to find their frequency and 
distribution across registers. These corpora are made up of various types of written texts (literary, academic, journalistic, and miscellaneous texts) and spoken texts (conversations, speeches, lectures, business meetings, TV/radio broadcasting) with hundreds of examples for each PUP.

All the English PUPs are then translated into Vietnamese. That the English PUPs have been translated into Vietnamese enables us to perform a comparative examination of the occurrence of the onomastic constituents. This process is known as decoding proper names. We carefully researched how the English PUPs in our database are translated into Vietnamese because PUs are often difficult to be grasped and translated into another language, especially when word-for-word translation of PUs with proper names is restricted.

According to Szerszunowicz (2008, pp. 118-121), as culture-bound components of PUs, proper names "carry cultural specificality" in themselves. Therefore, cultural allusions carried by a proper name must be properly interpreted in order to enable the whole PUP to be decoded. In the decoding process of English PUPs, we based on four translation strategies of idioms proposed by Baker (1990) along with composite classifications of English PUPs suggested by Pierini (2008) and Vrbinc (2016).

Most of the translations of the PUPs were double checked in the following four dictionaries: (1) English - Vietnamese Dictionary of Idioms, Nguyen Minh Tien,
Da Nang Publisher, 2004; (2) Kadict English - Vietnamese Dictionary of Idioms. MS Apps. Google Play Store; (3) Collection of Common Vietnamese - English Idioms, Proverbs and Folks, Nguyen Đinh Hung, Ho Chi Minh City Publisher, 2007; (4) English - Vietnamese Dictionary of Idioms, Trinh Thu Huong, Trung Dung, Vietnam's Women Publishing House, 2017. Besides, based on the examples and contexts provided by the corpora, we did our own translation of a small number of PUPs, which are unpopular or not found in any Vietnamese dictionaries. A simple Google search was then performed for "PUP + specific/generic suggested meaning" (e.g., "Gordon Bennett + ngạc nhiên") for any available translation of the PUPs. We then compared and valued these versions of translations including ours, and proposed a final translation of such PUPs.

It is noted that in our database a polysemous PUP with different senses was counted only once if it has one onomastic constituent.

\section{Results}

With regard to the translation of a PUP, it is the meaning of the PUP that should be analyzed first in order to be able to translate the phraseological meaning or to find a suitable equivalent in the target language. This process is known for decoding proper names. In this paper, it is not possible to include all 241 collected PUPs. Below are just a few examples of the groups found.

\section{Table 1}

Group 1 - Non-Idiomatic and Descriptive Translation Equivalents

\begin{tabular}{ll}
\multicolumn{1}{c}{ PUP } & \multicolumn{1}{c}{ Vietnamese translation equivalent } \\
\hline (and) Bob's your uncle & vậy nhé, thế là bạn có nó, thế là xong \\
\hline (go) tell it/that to Sweeney! & đi mà nói với trẻ con; chỉ có trẻ con mói tin \\
\hline
\end{tabular}




\begin{tabular}{ll}
\hline be sent to Coventry & bị tẩy chay, bị cô lập \\
\hline double Dutch & ngôn ngũu khó hiểu, điều khó hiểu \\
\hline Colonel Blimp & người thủ cựu, lạc hậu \\
\hline Freudian slip & lỡ lời, buột miệng, nói hớ \\
\hline in the land of Nod & say giấc nồng, ngủ say \\
\hline Jekyll and Hyde & người hai mặt, đa nhân cách, lúc tốt, lúc xấu \\
\hline keep up with the Joneses & cố vuơn cho đuợc bằng bạn bè/hàng xóm/mọi nguời \\
\hline raise Cain & gây rắc rối, gây rối loạn \\
\hline
\end{tabular}

Table 2

Group 2 - Idiomatic Translation Equivalents Without a Proper Name

\begin{tabular}{ll}
\hline \multicolumn{1}{c}{ PUP } & \multicolumn{1}{c}{ Vietnamese translation equivalent } \\
\hline as rich as Croesus & giàu nưt đố đổ vách \\
\hline build castles in Spain & mơ mộng hão huyền, xây lâu đài trên cát \\
\hline carry/take coals to Newcastle & chở củi về rùng \\
\hline Gordon Bennett & Trò̀i ơi; Ôi, trời \\
\hline it's (all) Greek to me & nhu vịt nghe sấm; nghe nhu tiếng Tây. \\
\hline rob Peter to pay Paul & giật gấu vá vai \\
\hline when in Rome (do as the Romans do) & nhập gia tùy tục \\
\hline
\end{tabular}

Table 3

Group 3 - Idiomatic Translation Equivalents With the Same Proper Name

\begin{tabular}{ll}
\hline \multicolumn{1}{c}{ PUP } & Vietnamese translation equivalent \\
\hline Achilles heel & gót chân Asin \\
\hline American Dream & giấc mo Mỹ \\
\hline Murphy's Law & dịnh luật Murphy \\
\hline Trojan horse & con ngụa thành To'-roa (Troy) \\
\hline Uncle Sam & chú Sam \\
\hline
\end{tabular}

Table 4

Group 4 - Idiomatic Translation Equivalents With a Different Proper Name

\begin{tabular}{ll}
\hline \multicolumn{1}{c}{ PUP } & Vietnamese translation equivalent \\
\hline (as) old as Adam & xua nhu Trái Đất \\
\hline As happy as Larry & vui nhu Tết \\
\hline Don Juan & Sở Khanh \\
\hline doubting Thomas & đa nghi nhu Tào Tháo \\
\hline Utopian dream & giấc mộng Nam Kha \\
\hline
\end{tabular}


Table 5

Translation Group Statistics

\begin{tabular}{ccc}
\hline Group & $\begin{array}{c}\text { Number of } \\
\text { PUPs }\end{array}$ & $\begin{array}{c}\text { Percentage of } \\
\text { PUPs }\end{array}$ \\
\hline Group 1 & 138 & 57.26 \\
Group 2 & 54 & 22.4 \\
Group 3 & 30 & 12.46 \\
Group 4 & 19 & 7.88 \\
\hline Total & $\mathbf{2 4 1}$ & $\mathbf{1 0 0}$ \\
\hline
\end{tabular}

As is evident from our database, nonidiomatic descriptive translation equivalents far exceed idiomatic translations of any kind, since non-idiomatic translation can be found in more than $60 \%$ of phraseological units with onomastic constituents as opposed to the less than $40 \%$ that account for the last three groups. However, the interesting code often hides itself in the group of idiomatic translation equivalents, especially ones with the same proper names, or other proper names with similar connotations. It is clear that decoding PUPs can be substantially influenced by extralinguistic factors.

\section{Discussion}

The groups identified in Section 5 clearly point out the complexity of translating PUPs as we must meditate on providing an idiomatic translation equivalent where possible. It should be noted that the connotations carried by the onomastic constituent can be of international, national or local characteristics.

Translating PUPs is a challenging but inspiring domain of translation studies. In order to translate PUPs from English into Vietnamese, the translator has to choose the most appropriate strategy or use various strategies, taking into account their peculiarities, function, culture specificity, semantic and structural unpredictability (Kovács, 2016). The challenges the translator may encounter when translating English PUs with proper names can be divided into two main categories.

a) Non-equivalence in Vietnamese

b) Equivalence in Vietnamese

Within each category, we try to identify and decode PUs with onomastic constituents. The causes of the translation difficulties as well as the pros and cons of the strategies employed are then analyzed.

\subsection{Identifying and Decoding English PUs With Onomastic Constituents}

Identifying a PU with an onomastic constituent is a prerequisite for proceeding with the next steps, which is entirely up to the translator. The truth is that the ability to recognize and understand a PUP correctly determines the successful translation of that PUP.

It is clear that the translator is not always able to grasp a certain PUP, especially when it holds various culturespecific meanings. If this is the case, it is difficult to successfully translate the PUP into Vietnamese. However, there exist PUPs that are quite universal in both English and Vietnamese, and not that difficult to be perceived in Vietnamese. It can be easier to deduce their metaphorical meanings. These are often PUPs with biblical, Greek mythical and classical names. Some examples are Achilles' heel, Trojan Horse, Adam's apple, etc.

However, the translator is not always so lucky, especially with the PUPs whose meaning is relatively opaque or the ones bearing cultural characteristics. It is not due to the PU with a proper name but the meaning it conveys and its associated domain to culturally specific contexts that makes it difficult to be identified and understood. Take send someone to Coventry as an example. The cultural characteristic of this PUP refers to Coventry, a placename. It is no problem to literally understand this phrase, but what it idiomatically means is 
not at all easy to be decoded. As explained by Cambridge University Press (n.d.), if a group of people send someone to Coventry, they refuse to speak to that person, usually as a punishment for having done something to upset the group. But why Coventry? There have been a few theories. One suggests it originates from the era of the English Civil War, when Parliamentarian supporters would take Royalist prisoners of war to Coventry. Once there, they would be shunned by city residents and inhabitants. However, if the translator had no idea what is behind the name Coventry, and the whole PU, and literally translate the PU into Vietnamese as "gứi ai tới Coventry", it would be a disaster.

Dutch courage is another example. The literal translation of this PUP will cause the reader to raise an eyebrow. In fact, the PUP is used to refer to courage or confidence gained from intoxication with alcohol (Cambridge University Press, n.d.). The etymology of the term involves some popular stories about English and Dutch soldiers in the Anglo-Dutch Wars during the $17^{\text {th }}$ century who drank jenever (Dutch gin) for calming or bravery-inducing effects before battle.

Due to differences in history, geographical location, customs and beliefs, social norms, etc., there are obviously a number of obstacles in the translation that make it difficult for people to accurately understand each other. Therefore, identifying and correctly understanding PUPs play an important role in the accurate translation of the language content, helping speakers of Vietnamese and English successfully communicate with each other.

\subsection{Non-Idiomatic Equivalence in Vietnamese}

Undoubtedly, as Kashgary (2011) affirms, non-equivalence is a fact that is happening in all languages and it has caused some untranslatable cases. Thus, when dealing with non-equivalence, it is recommended to focus on levels of linguistic uses in both languages.

Decoding PUs into the target language is never easy. As aforementioned, it is optimal to provide an equivalent $\mathrm{PU}$ in the target language. But in many cases, it is not possible to find any idiomatic equivalent, then the only translation way left is to explain, describe or paraphrase the English PUP. Translating English PUPs into Vietnamese in this case will present nonidiomatic equivalents that are descriptive. This approach drives the translator to use word-for-word translation, explain, annotate, or paraphrase the PUP, or translate figurative/idiomatic meaning only. Subsequently, certain translation loss is consequently unavoidable.

A certain meaning can be expressed with a fixed expression, an idiom, or just a single word in English, but it is not always the case in Vietnamese. Due to the lexical or stylistic differences between the two languages, certain correspondence will not always be found. Hence, the strategies recommended to be employed should be omission and paraphrase. English PUPs should be elaborated so that their meaning is better transferred to Vietnamese. It is noted here that the given meaning would not be an exact equivalent or semantic equivalent of the English PUs. A few examples are the man on the Clapham omnibus » ngườ bình thường, thường dân; Gordon Bennett » Trời oì! Ôi, trời; Freudian slip »lơ lời, buột miệng.

Another problem relating to nonequivalence is the literal translation of the PUP. Most translation researchers believe that idiomatic meanings may rarely be translated literally (see Larson, 1984; Newmark, 1988; Baker, 1992). For the purpose of transferring culture and information, however, literal translation of the English PUP can be employed as long as it brings about a decent translation effect and 
causes no misinterpretation of the message of the source PU. Literal translation is also an option where there is no equivalent $\mathrm{PU}$ in Vietnamese. It is noted that difficulties would emerge when the recognizable border between idiomatic and literal translation is not clear. Hence, a translator should be scrupulous to find them out and discover whether it is possible to translate literally.

However, for most English PUPs, it is necessary to base on the context to employ the appropriate translation solution. For example:

Ever since Kyle became a teenager, he's turned into a real Jekyll and Hyde, and it's impossible to anticipate his mood at any given time "Kể tù khi Kyle trở thành mọt thiếu niên, cậu ta đã trở nên lúc thế này, lúc thế kia, và thực sự không thể đoán truớc được tâm trạng của cậu ta tại bất kỳ thời điểm nào.

The phrase Jekyll and Hyde may be unknown to many Vietnamese if they have never read the book Strange Case of Dr. Jekyll and $\mathrm{Mr}$. Hyde by Robert Louis Stevenson. Jekyll and Hyde is a reference to the main character in the book whose personality drastically changes between good and bad.

In Vietnamese, there is no equivalent PU with a proper name depicting a person who is good now and bad then and vice versa. The word-for-word translation of each will mislead the message of the PUP. For such cases, translating with an explanation or annotation would be a better solution. Obviously, for the translation to be meaningful and effective, the translator may have to choose to ignore a certain element or replace it with another relatively close in terms of semantic domains and cognitive representations. Unless there is a corresponding PU in both form and content in Vietnamese, it is difficult to reproduce the PU used both literally and figuratively in the translation.
The PUP Rome was not built in one day » Thành La-Mã không phải được xây trong môt ngày is one of the few examples of effective word-for-word translation. In many other cases, Vietnamese people will not be able to readily understand PUPs without background knowledge about the economy, culture, and history hidden behind these proper names (Đô̂, 2015). To produce a decent translation, a loss of proper names would be inevitable as in the following examples: a castle in Spain » lâu đài trên cát; mo mộng hão huyền; fight like Kilkenny cats » chiến đấu tới hơi thơ cuối cùng.

The advantage of the literal translation of the PU is that it can preserve illustrative images and cultural specificality, contributing to cultural and language exchanges. However, many cases of literal translation can cause misunderstanding or fail to convey the complete domain of meanings of the PUPs, hence reducing the translation efficiency. Although the explanatory and annotated translation methods can convey the message of English PUPs, their weakest link is that they are quite lengthy and time-and-space consuming.

It can be seen that a greatest number of English PUPs are translated by means of a non-idiomatic equivalent of descriptive character. As a result, the neutral translation of the PU does not fully reflect the cultural aspects and the stylistic markedness may vanish (Szerszunowicz, 2008). Based on the stance by Fiedler (2007), we recommend that the PUPs with no equivalent in Vietnamese or with an equivalent based on a different metaphor be approached with great care, since it should be examined to what extent the new image is suitable for the context in English. In brief, in many cases, it is advisable to express the message of the PUP in a non-idiomatic way to ensure the highest possible translation quality from English to Vietnamese. 


\subsection{Idiomatic Equivalence in Vietnamese}

The ideal scenario in translation of the PUP is to find an idiomatic equivalent in both languages, such as the English idiom rob Peter to pay Paul which is equivalent to the Vietnamese idiom giật gấu vá vai. This is quite possible "because we human beings are in fact more alike than different", especially in closely value-sharing cultures as Lâm (2013, p. 76) put it. However, languages reflect different realities with different outlooks. As PUPs are linguistic units bearing rich cultural, social, geographic features, etc., of each language community, finding phraseological equivalents in translation is never easy, sometimes even impossible. Even when there are PU equivalents in both languages, they still pose a lot of problems for the translator. Some of the difficulties of having equivalent PUs in Vietnamese are to be discussed below.

\subsubsection{Idiomatic Translation Equivalent Without a Proper Name}

This way of idiomatic translation expresses the same metaphor in the source languages but with different lexical items. Equivalent images are ones that are understood and accepted in both cultures. An idiomatic equivalent or corresponding Vietnamese PU can express the figurative or symbolic meaning and effectively convey the cultural message of the English PUP. This is the case in which the target language owns a PU equivalent to the source PU in terms of meaning, style, definition, image, or nuance, etc. Let us study these examples.

- build castles in Spain » xây lâu đài trên cát [build castles on the sand] (1)

- carry coals to Newcastle » chở củi về rùng [carry firewood back to the forest] (2)

The choice of this method sometimes results in the risk of losing some source cultural image. However, its outstanding advantage is that both Vietnamese and
English use PUs with the similar figurative meanings and images (e.g., in Spain - trên cát, coals - củi, Newcastle - rùng). That they are equivalent in terms of images and nuances is highly effective at conveying most of the cultural messages expressed by the source PUs.

Idiomatic meaning of (1) is to form unattainable projects. While "build castles on the sand" (like in the air) is selfexplanatory, "build castles in Spain" requires some elucidation. This dated back to the time when Spain was in the hand of the Moore, and it was hard for French kings to conquer this land, hence impossible to build their own castles there. Similarly, in (2), the metaphor refers to doing something redundant, frivolous, or unnecessary. Newcastle was once a major coal supplier. In English, the contrasting pair is "coals Newcastle" while that in Vietnamese is "firewood - forest". Both PUs develop on the same image, i.e., to transport something to a place where there is already plenty. The symmetrical images of castle - Spain and coals - Newcastle are preserved in the target PUs (castle - sand, and firewood - forest), evoking the similar effect as the source PU.

In the two languages, however, corresponding idiomatic images are not always found. Here is an example about idiomatic translation equivalent with very different images and associations.

- it's (all) Greek to me » Nhu vit nghe sấm [Like a duck listening to thunderclaps] (4)

In the examples, the target and source PUs express the meaning of unintelligible language or gibberish (4). We have a mismatched image pair in English and Vietnamese (Greek - duck listening to thunderclaps). In example (4), no image of the source PUP is retained, even the nuance is completely different (the English PUP uses the adjective indicating the ethnic name with the object being first person singular the Vietnamese PU refers to the common 
name of an animal and a natural phenomenon).

These Vietnamese PUs represent corresponding idiomatic meanings, but comparative images in the PUs are not corresponding resulting in a loss of a certain amount of cultural information or characteristics of English. Also, dissimilar images and associations may stimulate different emotions from Vietnamese receivers leading to different conceptual metaphors.

\subsubsection{Idiomatic Translation Equivalent With a Different Proper Name}

These are interesting cases in which a PUP has the same figurative meaning with a different proper name in the target PUP. It is often possible to find an equivalent PU in Vietnamese consisting of a different proper name. Below are some examples.

- (as) old as Adam » xưa nhu Trái đất [old as Earth]

\section{character]}

- Don Juan » Sở Khanh [literary

- doubting Thomas » Đa nghi nhu Tào Tháo [as doubtful as Tao Thao (曹操)]

Proper names in the English PUPs and those in their Vietnamese equivalents have similar idiomatic name domains. The figurative and referential field of meaning given by such names is quite similar in both languages despite different proper names. For example, in Western cultures Don Juan is known as a legendary, fictional libertine. The name is used as a generic expression for a womanizer. In Vietnamese, So Khanh is a character from Nguyen Du's Tale of Kieu, who was infamous for cheating on women, including the title character, Thuy Kieu. Thus, So Khanh can be regarded as a full equivalent of Don Juan.

The challenges of finding idiomatic translation equivalents with a different proper name land on decoding connotative meanings of the source and target proper names. The translation of PUPs will be perfect if the English and Vietnamese proper names connote the same or similar objects or entities.

\subsubsection{Literal and Idiomatic} Translation Equivalents With the Same Proper Names

There are a few examples of this type such as American Dream, Murphy's Law, Trojan horse, Uncle Sam, etc. Most of them are the borrowings.

It should be pointed out that a number of PUPs with the same origin are more universally used in both English and Vietnamese. These include PUs with an anthroponym, toponym or a certain proper name whose connotation is universal. A few proper names in this type may have allusions to the Greek or Roman cultural heritage or ancient history. They may also come from a common context, be related to events of particular significance, be locations known from mythology or be universally known to most English and Vietnamese speakers. In both languages, all of these expressions are lexically similar, proving that the shared European linguistic and cultural heritage has had a significant influence on both English and Vietnamese PUPs. It is obvious that the existence of some common cultural denominators between different societies results from cultural exchanges and globalization. Globalization and translation made it possible for peoples of the world to "exchange knowledge, cope with the latest technology, and enjoy the good returns of modernity" (Al-Salman, 2007, p. 153).

The most typical PUPs of this type are the ones with borrowing names with classic references to Western literature. Although these PUPs may have become a part of the Vietnamese language, it does not mean all Vietnamese readers can understand them for the first time without some explanation. 
Take Achilles' heel as an example. An Achilles' heel is a weakness in spite of overall strength, which can lead to downfall (comparably tư huyệt in Vietnamese). The term alludes to the Greek mythology of the heroic warrior Achilles whose mother Thetis tried to make him immortal by holding the infant by his heel and plunging him into the River Styx. Eventually he was killed by an arrow shot into his undipped heel. This is to say why Achilles' heel is used to refer to one's deadly weak point.

If translated literally, the PUP Achilles' heel » gót chân Asin does not make much sense to Vietnamese readers, especially young readers who may not know the classic literary legend. For Vietnamese readers to understand this PUP or the alike, it is necessary to have a decent explanation of the literary reference, clarifying its symbolic and figurative meaning while retaining cultural images.

\subsubsection{Other PUP Translation Issues}

As aforementioned in Section 3, omission and compensation are sometimes inevitable in the PUP translation. It can be seen from the Vietnamese version, the "Lord Lucan" factor has been omitted under the strategy of omission. Besides, "do a Lord Lucan and flee" is merged into "biến mất $k h o i$ '. The reason for such an affair deals largely with the stylistic possessions of both Vietnamese and English. Instead, the phrase biến mất khỏi "compensates" the possible "loss" that the deletion of Lord Lucan may cause to the meaning. By omission, Baker (1992, p. 78) argues that getting this level right means that the target text "will feel less 'foreign' and, other factors being equal, may even pass for an original".

False friend and partial equivalence also cause difficulties for the translation of PUPs. Let us have a close look at a good Samaritan mentioned in Section 3. This PUP refers to a person who selflessly gives help and sympathy to people in times of trouble.
It is taken from a parable in the Bible in which a Samaritan man was the only person who stopped to help a man who was robbed and beaten (Farlex, n.d.). According to Hoàng (2007), Manh Thuong Quan can be either 1) a person who is very rich, loves good talents and often uses his money to do meaningful work; or 2) used to refer to financial helpers for a common job, an organization. Thus, Manh Thuong Quan is a very rich person with a good financial background, and as such is more commonly used in the sense of "sponsor". The sense that a person is compassionate and helpful to people in distress is not always highlighted in the Vietnamese version. This partial equivalence is supposed to help nourish 'false friends'.

Another example is Uncle Sam. Uncle Sam » Chú Sam is a common national personification of the U.S. federal government or the country. However, this PUP and its direct image (a tall, thin man with a white beard and a tall hat) have developed notoriety propagating imperialism and war around the world and been received in a non-positive sense. In Viet Nam, therefore, due to the historical problems, Uncle Sam may be attributed to a negative image, and is more often used to refer to "an aggressive U.S" or "a war-like, imperialist U.S administration".

It is obvious that false friends have been established since the PUPs, despite being identical, are not completely equivalent or just partial equivalent in terms of pragmatic sense. Therefore, we should take great care when encountering a "perfect equivalence" in terms of vocabulary, form, grammatical structure, and even a similar meaning. In addition, translators are urged to be vigilant with a number of different PUPs regarding cultural and national identities because the target Vietnamese PU could take away a certain cultural or ethnic characteristic of the source English one despite the PU in English and Vietnamese 
being identical.

In short, the translation of PUPs must be valid for both the Vietnamese language and the English language, not to hinder the expression of the source language in order to avoid the loss and deformation of the source language culture, leading to misinterpretation of PUPs.

\section{Conclusion}

English phraseological units with onomastic constituents (PUPs) have been explored in this paper. It is concluded that a proper interpretation of cultural allusions carried by proper names is a key to decoding the whole PUPs. The challenges in translating 241 PUPs were compiled, analyzed and categorized into the following four groups according to their Vietnamese translation equivalents: Non-idiomatic and descriptive translation, Idiomatic translation without a proper name, Idiomatic translation with the same proper name, and Idiomatic translation with a different proper name.

It is recommended that for a full comprehension of a PUP, the proper name factor must be thoroughly studied. The translator would face a hard task if he or she encounters English PUPs whose meaning is not the sum of the meanings of the constituents, or PUPs expressing both literal and figurative meanings, PUPs representing facts that do not exist in the world of the target, or PUPs being deeply culture-bound with multiple levels of metaphor. The translator should have knowledge about semantics and lexical sets in the English language to develop strategies to deal with non-equivalence in the semantic field. In addition, the translator should not forget that language and culture are closely related, especially in terms of PUPs and both aspects must be delicately deemed for translation. Literal translation should be considered the last resort because it often significantly reduces the informativeness of the cultural message even though in some cases it is justifiably necessary or unavoidable to retain integrity of the source message. Even with a Vietnamese equivalent, the translator still encounters many difficulties when translating PUPs from English into Vietnamese. This can be due to the origin of PUPs (in case of borrowings), different use of emotive images, different contexts, frequency of use or culture-bound elements.

To conclude, in order to boost the overall quality of the translation of PUPs and ensure the message conveyed in the source language is communicated to the audience of the target language (as the case of English and Vietnamese), it is of great importance to look into how PUPs work crosslinguistically in both languages and cultures. It is also urged that the translator be flexible in applying translation strategies and methods and rely on the context and purpose of using PUPs to decide on appropriate translation solutions. As Delisle and Woodsworth (1995) contends it is the translator that breaches the walls created by language differences, thereby opening up new horizons, paving the way for cultural exchanges and broadening vision of reality to encompass the entire world.

\section{References}

Al-Salman, S. M. (2007). Global English and the role of translation. The Asian EFL Journal, 9(4), 141-156.

Algeo, J. (1973). On defining the proper name. University of Florida Press.

Anderson, J. M. (2007). The grammar of names. Oxford University Press.

Aronoff, M., \& Rees-Miller, J. (2008). The handbook of linguistics. John Wiley \& Sons.

Awwad, M. (1990). Equivalence and translatability of English and Arabic idioms. Papers and Studies in Contrastive Linguistics, 26(57), 57-67.

Baker, M. (1992). In other words: A coursebook on translation. Routledge. 
Bassnett-McGuire, S. (1991). Translation studies. Routledge.

Belecky, A. (1972) Lexicology and language theory (onomastics). Izdatelstvovo kievskogo universiteta.

Cambridge University Press. (n.d.). Send sb to Coventry. In Cambridge dictionary. Retrieved November 10, 2020, from https://dictionary.cambridge.org/us/dictiona ry/english/send-sb-to-coventry

Catford, J. C. (1988). A linguistic theory of translation: An essay in applied linguistics. Oxford University Press.

Coates, R. (2006). Properhood. Language, 82(2), 356-382.

Dang, N. G. (2011). Idiom variants and synonymous idioms in English and Vietnamese: The similarities and differences. VNU Journal of Foreign Studies, 27(4), 273-280. https://js.vnu.edu.vn/FS/article/view/1493

Davies, M. G. (2004). Multiple voices in the translation classroom: Activities, tasks and projects. John Benjamins.

Delisle, J., \& Woodsworth, J. (1995). Translators through history. John Benjamins.

Dobrovol'skij, D. O., Piirainen, E., \& Dobrovolskij, D. (2005). Figurative language: Crosscultural and cross-linguistic perspectives. Elsevier.

Đỗ, T. T. H. (2015). Ý nghĩa biểu trưng của danh tù̀ riêng trong thành ngữ tiếng Việt [Symbolic meaning of proper nouns in Vietnamese idioms]. Trong Kỷ yếu Hội thảo Việt Nam hoc - Nhũng phuoong diện văn hóa truyền thống. Nxb Khoa học xã hội.

Farlex. (n.d.). Samaritan. In Farlex dictionary of idioms. Retrieved November 10, 2020, from https://idioms.thefreedictionary.com/S amaritan

Fiedler, S. (2007). English phraseology: A coursebook. Gunter Narr.

Glaser, R. (1998). The stylistic potential of phraseological units in the light of genre analysis. In A. P. Cowie (Ed.), Phraseology: Theory, analysis, and applications (pp. 125143). Clarendon Press.

Granger, S., \& Meunier, F. (2009). Phraseology in foreign language learning and teaching. Benjamins.

Hermans, T. (1988). On translating proper names, with reference to De Witte and Max Havelaar. In M. J. Wintle \& P. Vincent
(Eds.), Modern Dutch studies: Essays in honour of Professor Peter King on the occasion of his retirement (pp. 11-24). Athlone Press.

Hoàng, P. (2007). Tù điển tiếng Việt [Dictionary of the Vietnamese language]. Da Nang Publisher.

Hoàng, V. H. (2008). Thành ngũ học tiếng Việt [Vietnamese idioms]. Social Sciences Publisher.

Hough, C. (2000). Towards an explanation of phonetic differentiation in masculine and feminine personal names. Journal of Linguistics Cambridge, 36(1), 1-12.

Huddleston, R. (1988). English grammar: An outline. Cambridge University Press.

Kashgary, A. D. (2011). The paradox of translating the untranslatable: Equivalence vs. nonequivalence in translating from Arabic into English. Journal of King Saud University, 23(1), 47-57.

Koessler, M., \& Derocquigny, J. (1928). Les faux amis, ou, les trahisons du vocabulaire anglais (conseils aux traducteurs) [The false friends or the betrayals of English vocabulary (advice for translators)]. Libr. Vuibert.

Kovács, G. (2016). An evergreen challenge for translators - The translation of idioms. Acta Universitatis Sapientiae, Philologica, 8(2), 61-77. https://doi.org/10.1515/ausp-2016-0018

Kunin, A. V. (1970). Angliyskayafrazeologiya: Teoreticheskiy kurs [English phraseology: A theoretical course]. Vysshaya shkola.

Langlotz, A. (2006). Idiomatic creativity: A cognitive-linguistic model of idiomrepresentation and idiom-variation in English. J. Benjamins.

Larson, M. L. (1984). Meaning-based translation: A guide to cross-language equivalence. University Press of America.

Lâm, Q. Đ. (2013). Vietnamese and Korean: More alike than different. VNU Journal of Foreign Studies, 29(2), 76-83. https://js.vnu.edu.vn/FS/article/view/1091

Leppihalme, R. (1997). Culture bumps: An empirical approach to the translation of allusions (Topics in translation). Multilingual Matters.

Lions, J. (1977) Semantics. Cambridge University Press.

Long, T. H., \& Summers, D. (1996). Longman dictionary of English idioms. Longman. 
Moon, R. (1998). Fixed expressions and idioms in English: A corpus-based approach. Clarendon Press.

Newmark, P. (1988). A textbook of translation. Prentice Hall

Newmark, P. (1991). About translation. Multilingual Matters.

Nida, E. (1964). Toward a science of translating. E. J. Brill.

Nida, E. A., \& Taber, C. R. (1982). The theory and practice of translation. E. J. Brill.

Nuessel, F. (1992). The study of names: A guide to the principles and topics. Greenwood Press.

Pierini, P. (2008). Opening a pandora's box: Proper names in English phraseology. Linguistik Online, 36(4), 43-58. https://doi.org/10.13092/lo.36.518

Saleh, N. J., \& Weda, S. (2018). Indonesian poetry translation: The problem within. Journal of English as International Language, 13(2.2), 64-87.
Shojaei, A. (2012). Translation of idioms and fixed expressions: Strategies and difficulties. Theory and Practice in Language Studies, 2(6), 1220-1229.

Szerszunowicz, J. (2008). Decoding phraseological units as a socio-linguistic problem (on the example of onomastic idioms). In D. Susniene (Ed.), Nation and language: Modern aspects of socio-linguistic development. Proceedings of the 3rd international conference (pp. 118-121). Kaunas University of Technology, Panevėžys Institute.

Vrbinc, A. (2019). A cross-linguistic and crosscultural analysis of English and Slovene onomastic phraseological units. Cambridge Scholars Publishing.

Vrbinc, M. (2016). English phraseological units with an onomastic element and their translation equivalents in Slovene. Coll Antropol, 40(1), 41-47.

Weiss, A. S. (2019). Imaginary onomastics. Translation Studies, 12(1), 100-108. 


\title{
KHÓ KHĂN TRONG VIỆC DỊCH TỔ HỢP THÀNH NGŨ̉ TÍNH TIẾNG ANH CÓ THÀNH TỐ TÊN RIÊNG SANG TIẾNG VIẸTT
}

\author{
Nguyễn Việt Khoa \\ Viện Ngoại ngũu, Đại học Bách khoa Hà Nội, \\ Số 1 Đại Cồ Việt, Hà Nội, Việt Nam
}

Tóm tắt: Tổ hợp thành ngữ tính có thành tố tên riêng là một chủ đề thu hút nhiều nghiên cứu trong giới dịch thuật ngày nay. Các tổ hợp thành ngữ loại này luôn phản ánh văn hóa và tâm lý dân tộc của mỗi quốc gia. Có khá nhiều nghiên cứu trên thế giới về vấn đề này ở nhiều cặp ngôn ngữ khác nhau, nhưng chưa có nghiên cứu phân tích chuyên sâu những khó khăn trong quá trình dịch các tổ hợp này trong cặp ngôn ngữ Anh-Việt. Bằng cách sử dụng phương pháp nghiên cứu định tính, bài báo trình bày kết quả nghiên cứu trong đó 241 tổ hợp thành ngữ tính tiếng Anh có thành tố tên riêng được thu thập và phân loại thành bốn nhóm theo bản dịch tiếng Việt. Việc nhóm đơn vị tương đương mang tính mô tả và mất đi tính thành ngữ chiếm phần lớn với hơn $57 \%$ số tổ hợp chứng tỏ rằng tổ hợp thành ngữ tính có thành tố tên riêng ở cả hai ngôn ngữ đều mang tính đặc trưng văn hóa cao. Mặc dù ba nhóm còn lại chia sẻ một thiểu số xấp xỉ $43 \%$ tổng số tổ hợp, nhưng chúng lại mang nhiều ẩn số thú vị với nhiều cấp độ ẩn dụ tương đồng hay dị biệt ở cả hai ngôn ngữ. Dựa trên kết quả nghiên cứu, bài báo nêu lên những thách thức mà người dịch gặp phải trong quá trình dịch các tổ hợp thành ngữ tính tiếng Anh có thành tố tên riêng sang các đơn vị tương đương trong tiếng Việt, trong đó tên riêng nổi lên như là một trong những thách thức lớn nhất. Bài báo đề xuất một số giải pháp dịch thuật để xử lý hiệu quả các biểu thức đặc biệt này. Ngoài việc khuyến nghị áp dụng linh hoạt các chiến lược dịch thuật, kết luận của của bài báo cũng nhấn mạnh rằng chỉ khi người dịch giải mã và nắm bắt được cách thức hoạt động của các tổ hợp thành ngữ tính có thành tố tên riêng trong cả hai ngôn ngữ và hai nền văn hóa thì họ mới có thể thực hiện thành công việc dịch thuật các tổ hợp này.

Từ khóa: tổ hợp thành ngữ tính, tên riêng, danh xưng học, thành ngữ, cụm từ cố định 